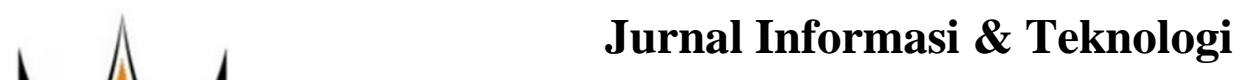

http://www.jidt.org

\title{
Prediksi Mahasiswa Berpotensi Non Aktif Menggunakan Data Mining dalam Decision Tree dan Algoritma C4.5
}

\author{
Nur Yanti Lumban Gaol ${ }^{\square}$ \\ STMIK Triguna Dharma \\ ryanti2918@gmai1.com
}

\begin{abstract}
Non-active students are students who do not attend the lecture process and do not pay tuition administration fees within two semesters or more. Reports on students who are not active will have an impact on the quantity of tertiary institutions. Students who are not registered in non-active students will potentially be expelled or dropped out. For this reason, this research was conducted to explore information on potentially non-active students by applying data mining science with the Decision Tree method and C4.5 algorithm. The tested data were sourced from Triguna Dharma Medan College of Information and Computer Management (STMIK). The results of the study get prediction rules for student data that are potentially non-active with a very good degree of accuracy. So this research can be used to avoid students dropping out unilaterally.
\end{abstract}

Keywords: Data Mining, Decision Tree, C4.5 Algorithm, Rapid Miner, Non-active students, Drop out.

\begin{abstract}
Abstrak
Mahasiswa non aktif adalah mahasiswa yang tidak mengikuti proses perkuliahan dan tidak membayar biaya administrasi kuliah dalam waktu dua semester atau lebih. Laporan tentang mahasiswa yang tidak aktif akan berdampak terhadap kuantitas perguruan tinggi. Mahasiswa yang tidak terdata dalam mahasiswa non aktif akan berpotensi untuk dikeluarkan atau drop out. Untuk itu dilakukan penelitian ini untuk menggali informasi terhadap mahasiswa yang berpotensi non aktif dengan penerapan ilmu data mining dengan metode Decision Tree dan algoritma C4.5. Data yang diuji bersumber dari Sekolah Tinggi Manajemen Informatika dan Komputer (STMIK) Triguna Dharma Medan. Hasil penelitian mendapatkan rule prediksi data mahasiswa yang berpotensi non aktif dengan tingkat keakurasian yang sangat baik. Sehingga penelitian ini dapat digunakan untuk menghindari mahasiswa drop out secara sepihak.
\end{abstract}

Kata kunci: Decision Tree, Algoritma C4.5, Rapid Miner, Mahasiswa non aktif, Drop out.

(C) $2020 \mathrm{JIdT}$

\section{Pendahuluan}

Mahasiswa non aktif merupakan mahasiswa tidak mengikuti perkuliahan paling lama 2 (dua) semester berturut-turut. Mahasiswa non aktif memiliki kemungkinan untuk dikeluarkan (drop out) pada sebuah perguruan tinggi. Mahasiswa yang berpotensi untuk di drop out dari kampus biasa dilatarbelakangi oleh terhentinya proses perkuliahan. Alasan utama terjadinya ketidak aktifan tesebut adalah tidak melakukan pembayaran biaya administrasi.

Banyaknya mahasiswa yang dikeluarkan akan beradmpak terhadap mutu perguruan tinggi. Untuk itu pihak perguruan tinggi harus melakukan monitoring dan evaluasi dalam pelaksaan sistem pembelajaran secara berkala dan mendata keaktifan mahasiswanya. Pendataan ini akan meningkatkan mutu sebuah perguruan tinggi [1].

Untuk menghindari terjadinya pemberhentian mahasiswa, maka perlu pendataan mahasiswa yang tidak aktif dan memprediksi akan terjadinya ketidakaktifan proses perkuliahan. Hal yang melatarbelakangi proses analisa terhadap permasalahan tersebut akan dapat diketahui faktor penyebabnya.

Berdasarkan hal tersebut perlu dilakukan penelitian untuk memprediksi mahasiswa yang berpotensi non aktif. Metode yang digunakan untuk mengolah datanya adalah Decision Tree dengan algoritma C4.5.

Decision Tree merupakan sebuah Knowledge Discovery In Database (KDD). Hasil dari metode ini akan mendapatkan sebuah pengetahuan dari database yang diolah. Database akan diekstraksi sehingga menghasilkan informasi atau pengetahuan yang berguna [2]. Tahap-tahapan yang dilakukan dalam KDD adalah data mining. Data mining merupakan suatu algoritma di dalam menggali informasi berharga yang terpendam (tersembunyi) pada koleksi data (database) yang sangat besar, sehingga ditemukan suatu pola menarik yang sebelumnya tidak diketahui [3]. Salah satu algoritma yang digunakan dalam data mining adalah algoritma $\mathrm{C} 4.5$.

Algoritma C4.5 merupakan algoritma yang digunakan untuk membentuk pohon keputusan dan aturan aturan (rule). Algoritma C4.5 memetakan nilai atribut 
menjadi kelas yang dapat diterapkan untuk klasifikasi baru [4].

Beberapa penelitian yang menggunakan algoritma C4.5 diantaranya adalah Lorenza dkk (2014) menggunakan Algoritma C4.5 untuk memprediksi masa studi mahasiswa berdasarkan data nilai akademik. Hasil yang didapatkan melalui penelitian tersebut memberikan pengaruh besar terhadap nilai persentase kecocokan dan keakurasian dalam memprediksi masa studi mahasiswa berdasarkan data nilai akademik [5]. Harryanto \& Hansun (2017) menggunakan algoritma C4.5 untuk memprediksi penerimaan calon pegawai baru pada PT.WISE, serta memberikan hasil pengujian terhadap keakurasian proses prediksi kepada calon pegawai [6]. Penelitian Melissa \& Oetama (2013) menggunakan data mining untuk melakukan analisis data pembayaran kredit nasabah bank. Hasil penelitian dapat mengoptimalkan prediksi pembayaran kredit nasabah bank [7].

Penelitian Novriansyah dkk (2017) menggunakan data mining dan algoritma Naive Bayes untuk mengetahui minat beli pelanggan terhadap kartu internet XL. Hasil didapatkan bahwa metode klasifikasi dan algoritma Naive Bayes sangat cocok dipakai untuk memberikan prediksi yang dapat dipakai di masa depan [8].

\section{Metodologi Penelitian}

Penelitian ini menggunakan teknik klasifikasi yang terbagi menjadi pohon keputusan (Decesion Tree). Metode klasifikasi yang digunakan untuk proses permodelan dalam menggambarkan dan membedakan kelas data atau konsep label kelas yang tidak diketahui [9]. Pohon keputusan merupakan salah satu metode klasifikasi dan prediksi yang sangat kuat dan terkenal. Tujuan klasifikasi ini untuk menemukan model dari training set yang membedakan atribut ke dalam kategori atau kelas yang sesuai [10]. Pohon keputusan digunakan untuk mengubah fakta yang sangat besar untuk mempresentasikan aturan.

Algoritma C4.5 merupakan kelompok algoritma decision tree yang ditemukan oleh Quinlan [11]. Dalam membangun pohon keputusan memilih beberapa tahapan, yaitu pemilihan atribut sebagai akar; membuat cabang untuk tiap - tiap nilai; membagi kasus dalam cabang; dan mengulangi proses untuk setiap cabang sampai semua kasus pada cabang memiliki kelas yang sama [12]. Algoritma mempunyai input berupa training samples dan samples. Training samples adalah berupa data contoh yang digunakan untuk membangun sebuah tree yang telah diuji kebenarannya. Sedangkan samples merupakan fieldfield data yang nantinya akan digunakan sebagai parameter dalam melakukan klasifikasi data.

\section{Hasil dan Pembahasan}

Data yang dianalisa adalah data mahasiswa yang aktif dan non aktif pada Sekolah Tinggi Manajemen Informatika dan Komputer (STMIK) Triguna Dharma Medan. Data diklasifikasikan dengan menggunakan proses data mining, Decision Tree dan algoritma C4.5. Pengolahan data mahasiswa non aktif terdiri dari 4 kriteria yang disajikan pada tabel 1 dan data sampel disajikan pada tabel 2.

Tabel 1. Tabel Data Kriteria Mahasiswa Berpotensi non aktif

\begin{tabular}{cc}
\hline No & Data Variabel \\
\hline 1 & Jadwal Kuliah \\
\hline 2 & Nilai Absensi \\
\hline 3 & Nilai Gagal \\
\hline 4 & Pembayaran Uang Kuliah \\
\hline
\end{tabular}

Tabel 2. Tabel Sample Data Mahasiswa

\begin{tabular}{|c|c|c|c|c|c|c|c|c|c|c|}
\hline No & Nama & Alamat & $\begin{array}{l}\text { Tanggal Lahir } \\
\text { Lahir }\end{array}$ & Agama & $\begin{array}{l}\text { Jadwal } \\
\text { Kuliah }\end{array}$ & Absen & $\begin{array}{l}\text { Nilai } \\
\text { Gagal }\end{array}$ & $\begin{array}{l}\text { Pembayaran } \\
\text { Uang Kuliah }\end{array}$ & Status & Absen \\
\hline 1 & $\begin{array}{l}\text { Santi } \\
\text { Gandhi }\end{array}$ & $\begin{array}{l}\text { Kelurahan } \\
\text { Kampung Lalang }\end{array}$ & $\begin{array}{l}28 / 06 / 1997 \\
1998 \\
\end{array}$ & Islam & sore & 4 & 1 & Menunggak & Non aktif & 4 \\
\hline 2 & $\begin{array}{l}\text { Andre } \\
\text { Pradana }\end{array}$ & Jl. Resmi & $\begin{array}{l}05 / 10 / 1996 \\
1994\end{array}$ & Islam & Sore & 4 & 0 & $\begin{array}{l}\text { Tidak } \\
\text { Menunggak }\end{array}$ & Aktif & 4 \\
\hline 3 & $\begin{array}{l}\text { Reza } \\
\text { ArieIkhwan }\end{array}$ & $\begin{array}{l}\text { Jl. Budi } \\
\text { Penerbangan No. } \\
10 \text { Kel. }\end{array}$ & $\begin{array}{l}15 / 03 / 1996 \\
1996\end{array}$ & Islam & Sore & 2 & 0 & $\begin{array}{l}\text { Tidak } \\
\text { Menunggak }\end{array}$ & Aktif & 2 \\
\hline 4 & $\begin{array}{l}\text { Dimas } \\
\text { Pamungkas }\end{array}$ & Jl. TSutrisno & $\begin{array}{l}09 / 05 / 1993 \\
1997 \\
\end{array}$ & Islam & Pagi & 12 & 11 & Menunggak & Non aktif & 12 \\
\hline 5 & Jaka & $\begin{array}{l}\text { Jl. A. H. Nasutio } \\
\text { Gg. Rapi Medan }\end{array}$ & $\begin{array}{l}17 / 09 / 1994 \\
1995\end{array}$ & Kristen & Sore & 4 & 2 & $\begin{array}{l}\text { Tidak } \\
\text { Menunggak }\end{array}$ & Aktif & 4 \\
\hline 6 & Anisa & $\begin{array}{l}\text { Jl. SM. Raja } \\
\text { Simp. Limun No. } \\
89\end{array}$ & $\begin{array}{l}24 / 04 / 1996 \\
1995\end{array}$ & Kristen & Sore & 3 & 0 & $\begin{array}{l}\text { Tidak } \\
\text { Menunggak }\end{array}$ & Aktif & 3 \\
\hline 7 & $\begin{array}{l}\text { Eva } \\
\text { Kamenia } \\
\text { Pakpahan }\end{array}$ & $\begin{array}{l}\text { Jl. Melayu Desa } \\
\text { Tumpatan Kec. } \\
\text { Beringin }\end{array}$ & $\begin{array}{l}13 / 07 / 1997 \\
1998\end{array}$ & Kristen & Sore & 2 & 1 & $\begin{array}{l}\text { Tidak } \\
\text { Menunggak }\end{array}$ & Aktif & 2 \\
\hline
\end{tabular}


Banyak data yang diuji berjumlah 57 orang mahasiswa, tetapi yang disajikan hanya 7 orang mahasiswa. Selanjutnya data tersebut dilakukan proses cleaning dan transformasi data. Data mahasiswa yang aktif dan non aktif akan dilakukan proses transformasi. Terlebih dahulu diklasifikasikan sesuai dengan peraturan dan ketetapan regulasi kampus. Klasifikasi pertama yaitu jadwal kuliah. Klasifikasi ini disajikan pada tabel 3. kedua yaitu nilai absensi, yang disajikan pada tabel 4 , ketiga yaitu nilai gagal yang disajikan pada tabel 5, keempat yaitu status pembayaran uang kuliah yang disajikan pada tabel 6 .

Tabel 3. Klasifikasi Jadwal Kuliah

\begin{tabular}{ccc}
\hline No & Jadwal Kuliah & Klasifikasi \\
\hline 1 & Kelas A & Pagi \\
\hline 2 & Kelas B & Siang \\
\hline 3 & Kelas C & Sore \\
\hline
\end{tabular}

Tabel 4. Klasifikasi Nilai Absensi

\begin{tabular}{ccc}
\hline No & Nilai Absensi & Klasifikasi \\
\hline 1 & $0-4$ & Aman \\
\hline 2 & $5-8$ & SP \\
\hline 3 & $>8$ & Mengulang \\
\hline
\end{tabular}

Tabel 5. Klasifikasi Nilai

\begin{tabular}{ccc}
\hline No & Nilai Gagal & Klasifikasi \\
\hline 1 & $<=5$ & Aman \\
\hline 2 & $6-10$ & SP \\
\hline 3 & $>10$ & Mengulang \\
\hline
\end{tabular}

Tabel 6. Klasifikasi Uang Kuliah

\begin{tabular}{ccc}
\hline No & Pembayaran Uang Kuliah & Klasifikasi \\
\hline 1 & Tepat waktu & Tidak Menunggak \\
\hline 2 & Tidak Tepat Waktu & Menunggak \\
\hline
\end{tabular}

Selanjutnya dilakukan proses transformasi terhadap sampel data yang disesuaikan dengan Tabel klasifikasi yang telah ada. Hasil transformasi data sampel disajikan pada tabel 7 .

Tabel 7. Sampel Data Cleaning dan Transformasi

\begin{tabular}{|c|c|c|c|c|c|}
\hline No & Jadwal Kuliah & Absen & Nilai & $\begin{array}{c}\text { Status Pembayaran Uang } \\
\text { Kuliah } \\
\end{array}$ & Status \\
\hline 1 & Sore & Aman & Aman & Menunggak & Non aktif \\
\hline 2 & Sore & Aman & Aman & Tidak Menunggak & Aktif \\
\hline 3 & Sore & Aman & Aman & Tidak Menunggak & Aktif \\
\hline 4 & Pagi & Mengulang & Aman & Menunggak & Non aktif \\
\hline 5 & Sore & Aman & Aman & Tidak Menunggak & Aktif \\
\hline 6 & Sore & Aman & Aman & Tidak Menunggak & Aktif \\
\hline 7 & Sore & SP & Aman & Tidak Menunggak & Aktif \\
\hline
\end{tabular}

\subsection{Mencari Entropy Total}

Mencari nilai entropy total untuk dijadikan sebagai node 1. Jumlah data yang digunakan berjumlah 107 ,

Tabel 8. Pengelompokan Data Mahasiswa

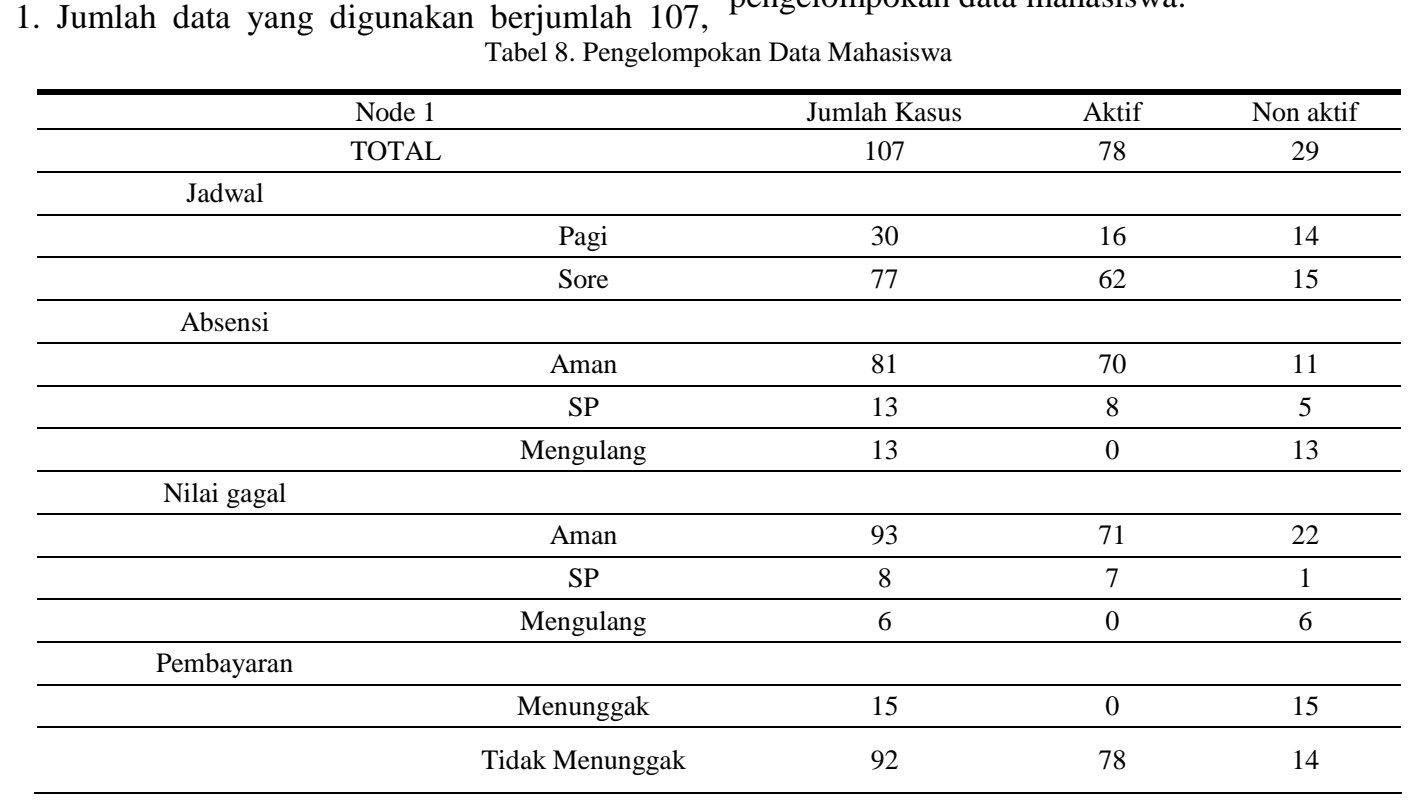

Jurnal Informasi \& Teknologi Vol. 2 No. 1 (2020) 23-29 dimana data mahasiswa aktif sebanyak 78 orang dan non aktif 29 orang mahasiswa. Pada tabel 8 dilakukan pengelompokan data mahasiswa. 
Setelah data yang ditransformasikan dikelompokkan, selanjutnya mencari nilai entropy dari semua atribut untuk dijadikan entropy total.

Perhitungan Entropy dan Gain pada node 1 :

$=\left(-78 / 107 * \log _{2} 78 / 107\right)+\left(-29 / 107 * \log _{2} 29 / 107\right)$ $=0,84293$.

\subsection{Mencari Entropy dan Gain pada semua atribut}

Setelah menghitung nilai Entropy total, berikutnya menghitung nilai setiap atribut berdasarkan klasifikasi yang ditentukan. Klasifikasi pada atribut jadwal kuliah terdapat 2 klasifikasi yaitu pagi dan sore.

- Entropy jadwal kuliah (pagi)

$=(-16 / 30 * \log 216 / 30)+(-14 / 30 * \log 214 / 30)=$ 0,99679
- Entropy jadwal kuliah (sore)

$=(-62 / 77 * \log 262 / 77)+(-15 / 77 * \log 215 / 77)=$ 0,71141

Selanjutnya menghitung nilai gain untuk atribut jadwal kuliah, dan nilai Gain tertinggi akan menjadi node 1 .

- Information Gain (total, jadwal kuliah)

$$
=0,842936-((30 / 107 * 0,996792)+(77 / 107 *
$$$$
0,711416))=0,05150
$$

Setelah menghitung nilai Entropy dan nilai Gain untuk jadwal kuliah, selanjutnya lakukan hal yang sama untuk kembali menghitung nilai Entropy dan nilai Gain untuk atribut yang lainnya. Tabel 9 adalah tabel hasil perhitungan manual untuk nilai Entropy dan nilai Gain yang dipakai untuk menentukan node akar.

Tabel 8. Pengelompokan Data Mahasiswa

\begin{tabular}{|c|c|c|c|c|c|c|}
\hline \multicolumn{2}{|c|}{$\begin{array}{l}\text { Perhitungan } \\
\text { Node } 1\end{array}$} & Jumlah Kasus & Aktif & $\begin{array}{l}\text { Non } \\
\text { Aktif }\end{array}$ & Entropy & Gain \\
\hline \multicolumn{2}{|c|}{ Total } & 107 & 78 & 29 & 0,842 & \\
\hline \multirow[t]{3}{*}{ Jadwal Kuliah } & & & & & & 0,051 \\
\hline & Pagi & 30 & 16 & 14 & 0,996 & \\
\hline & Sore & 77 & 62 & 15 & 0,711 & \\
\hline \multirow[t]{4}{*}{ Absensi } & & & & & & 0,292 \\
\hline & Aman & 81 & 70 & 11 & 0,573 & \\
\hline & SP & 13 & 8 & 5 & 0,961 & \\
\hline & Mengulang & 13 & 0 & 13 & 0 & \\
\hline \multirow[t]{4}{*}{ Nilai Gagal } & & & & & & 0,116 \\
\hline & Aman & 93 & 71 & 22 & 0,789 & \\
\hline & SP & 8 & 7 & 1 & 0,543 & \\
\hline & Mengulang & 6 & 0 & 6 & 0 & \\
\hline \multirow[t]{3}{*}{$\begin{array}{c}\text { Pembayaran Uang } \\
\text { Kuliah } \\
\end{array}$} & & & & & & 0,313 \\
\hline & Menunggak & 15 & 0 & 15 & 0 & \\
\hline & Tidak Menunggak & 92 & 78 & 14 & 0,615 & \\
\hline
\end{tabular}

Dari tabel 8 diketahui bahwa atribut dengan gain tertinggi adalah pembayaran uang kuliah sebesar 0,313. Hasil pohon keputusan pada gambar 1 .

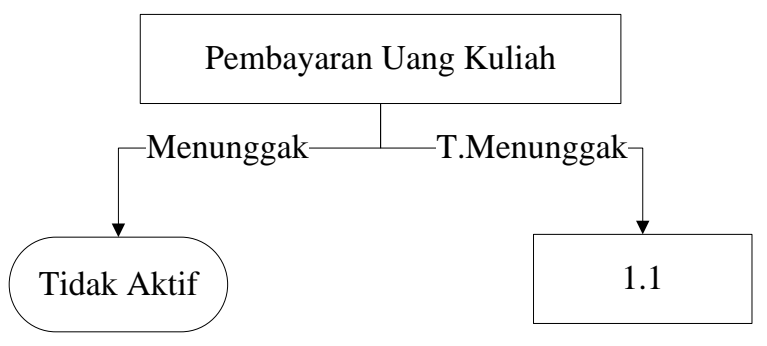

Gambar 1. Pohon Keputusan Node 1

\subsection{Menentukan Node cabang}

Setelah mendapatkan node 1 , selanjutnya mencari atribut mana yang akan menjadi cabang level 1 . Langkah - langkah untung menghitung cabang level 1 adalah dengan menghitung kembali Entropy atribut pembayaran uang kuliah dengan klasifikasi tidak menunggak.

- Entropy pembayaran uang kuliah (tidak menunggak) $=\left(-78 / 92 * \log _{2} 78 / 92\right)+\left(-14 / 92 * \log _{2} 14 / 92\right)=$ 0,61525

Atribut yang masih dapat digunakan sebagai cabang level 1 yaitu jadwal kuliah, nilai gagal dan nilai absensi. Atribut jadwal kuliah terdapat 2 klasifikasi yaitu pagi dan sore. 
- Entropy jadwal kuliah (pagi) $=\left(-16 / 24 * \log _{2} 16 / 24\right)+\left(-8 / 24 * \log _{2} 8 / 24\right)=$
0,91829

- Entropy jadwal kuliah (sore)

$=\left(-62 / 68 * \log _{2} 62 / 68\right)+\left(-6 / 68 * \log _{2} 6 / 68\right)=$ 0,43055 .

Selanjutnya menghitung nilai gain untuk atribut jadwal kuliah. Nilai Gain akan digunakan sebagai perbandingan dengan atribut lainnya. Nilai Gain tertinggi akan menjadi cabang level 1 .

Tabel 9. Hasil Perhitungan Node 1.1

\begin{tabular}{ccccccc}
\hline $\begin{array}{c}\text { Perhitungan } \\
\text { Node 1.1 }\end{array}$ & $\begin{array}{c}\text { Jumlah } \\
\text { Kasus }\end{array}$ & Aktif & Non Aktif & Entropy & Gain \\
\hline Total & 92 & 78 & 14 & 0,615 & \\
\hline Jadwal Kuliah & Pagi & 24 & 16 & 8 & 0,918 & \\
\hline & Sore & 68 & 62 & 6 & 0,430 & \\
\hline Absensi & & & & & & 0,369 \\
\hline & Aman & 73 & 70 & 3 & 0,247 & \\
\hline SP & 9 & 8 & 1 & 0,503 & \\
\hline Nilai Gagal & Mengulang & 10 & 0 & 10 & 0 & \\
\hline & Aman & 81 & 71 & 10 & 0,539 & \\
\hline & SP & 7 & 7 & 0 & 0 & \\
\hline & Mengulang & 4 & 4 & 0 & 0 & \\
\hline
\end{tabular}

Berdasarkan tabel diatas diketahui bahwa atribut dengan Gain tertinggi adalah atribut nilai absensi sebesar 0,369, maka nilai absensi dijadikan sebagai Node 1.1. Dari hasil tersebut didapatlah pohon keputusan seperti pada gambar 2.

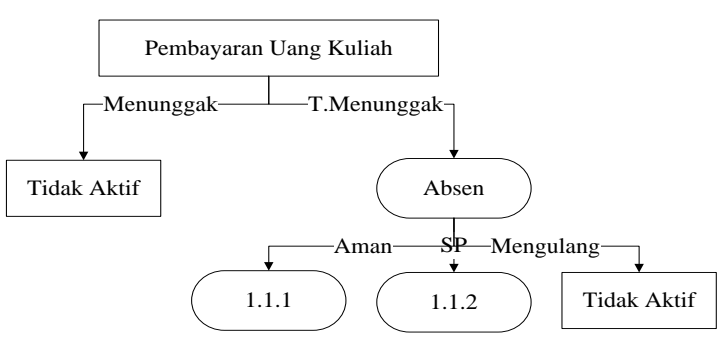

Gambar 2. Pohon Keputusan Node 1.1
- Information Gain (total, jadwal kuliah)

$$
=0,615254-((24 / 92 * 0,91829)+(68 / 92 *
$$$$
0,43055))=0,05746
$$

Selanjutnya lakukan hal yang sama untuk kembali menghitung nilai entropy dan nilai gain untuk atribut yang lainnya. tabel 9 adalah tabel untuk mendapatkan Gain yang tertinggi. pohon keputusan Node 1.1, dapat menggunakan nilai

Setelah mendapatkan node 1.1, selanjutnya dilanjutkan dengan perhitungan nilai Entropy pada nilai absensi (aman), Entropy jadwal kuliah (pagi), Entropy jadwal kuliah (sore) untuk mencari cabang Level 1.1.1 seperti proses pada tahapan sebelumnya. Hingga didapatlah hasil perhitungan untuk dijadikan sebagai Node 1.1.1 seperti pada tabel 10.

Tabel 10. Hasil Perhitungan Node 1.1.1

\begin{tabular}{|c|c|c|c|c|c|}
\hline Perhitungan Node 1.1 & Jumlah Kasus & Aktif & Non Aktif & Entropy & Gain \\
\hline Total & 73 & 70 & 3 & 0,247 & \\
\hline Jadwal Kuliah & & & & & 0,010 \\
\hline Pagi & 12 & 12 & 0 & 0,918 & \\
\hline Sore & 61 & 58 & 3 & 0,282 & \\
\hline Nilai Gagal & & & & & 0,247 \\
\hline Aman & 63 & 63 & 0 & 0 & \\
\hline SP & 7 & 7 & 0 & 0 & \\
\hline Mengulang & 3 & 0 & 3 & 0 & \\
\hline
\end{tabular}


Berdasarkan tabel diatas diketahui bahwa atribut dengan gain tertinggi adalah atribut nilai gagal sebesar 0,247, maka nilai gagal dijadikan sebagai Node 1.1.1.

Dari hasil tersebut didapatlah pohon keputusan seperti pada Gambar 3.

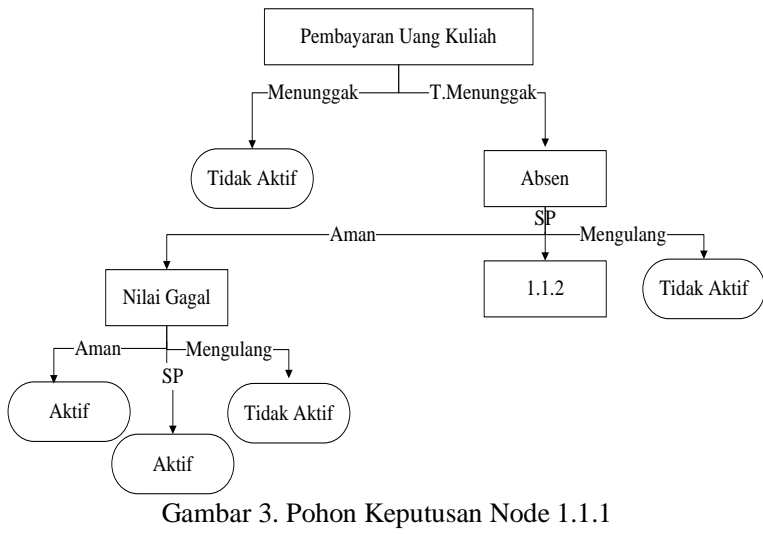

Selanjutnya menghitung nilai Entropy pada Node 1.1.2. Klasifikasi nilai aman dan mengulang tidak perlu lagi

dihitung karena sudah bernilai 0. Selanjutnya yang dihitung adalah nilai Entropy pada atribut yang lain,

dengan menggunakan nilai dari atribut nilai gagal dengan klasifikasi aman sebagai nilai Entropy total untuk mendapatkan Node 1.1.2 pohon keputusan Node 1.1.2 terlihat pada Tabel 11.

Tabel 11. Hasil Perhitungan Node 1.1.2

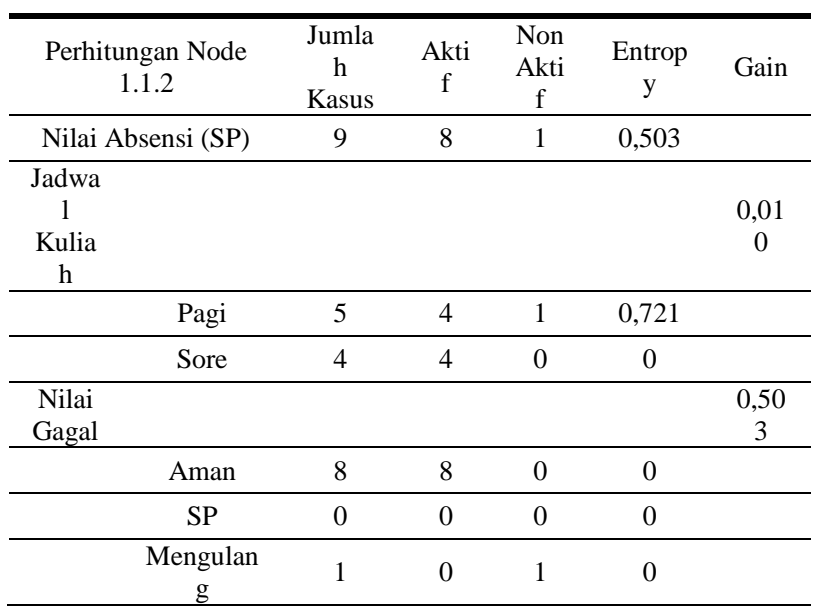

Berdasarkan tabel diatas diketahui bahwa atribut dengan Gain tertinggi adalah atribut nilai gagal sebesar 0,503. Dengan demikian atribut nilai absen dijadikan Node 1.1.2. Dari hasil tersebut didapatlah pohon keputusan seperti pada Gambar 4.

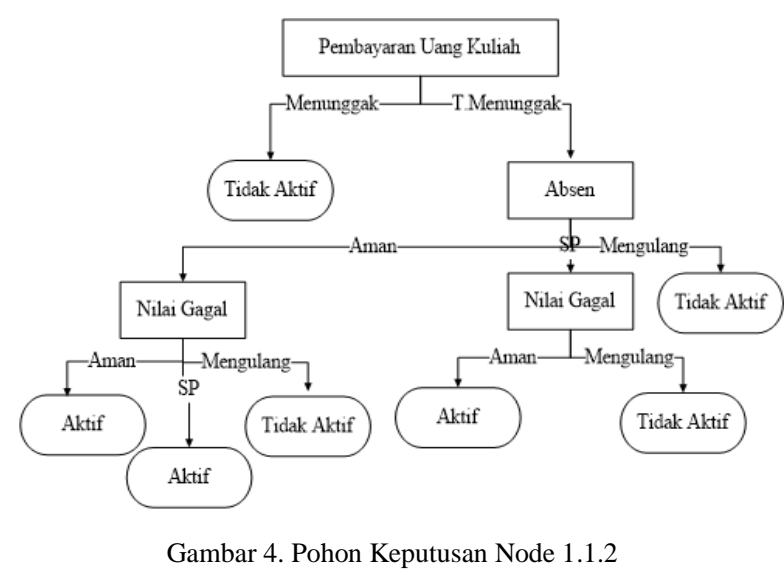

Setelah proses perhitungan selesai, maka didapatlah sebuah pohon keputusan dengan aturan (rule) yaitu :

- IF “Pembayaran Uang Kuliah "Menunggak" THEN "Non aktif"

- IF "Pembayaran Uang Kuliah "Tidak Menunggak" AND Absen "Aman" AND Nilai "Aman" THEN "Aktif"

- IF "Pembayaran Uang Kuliah "Tidak Menunggak" AND Absen "Aman" AND Nilai "SP" THEN "Aktif"

- IF "Pembayaran Uang Kuliah Tidak Menunggak" AND Absen “ Aman" AND Nilai "Mengulang " THEN "Non aktif"

- IF "Pembayaran Uang Kuliah Tidak Menunggak" AND Absen "SP" AND Nilai "Aman" THEN "Aktif"

- IF "Pembayaran Uang Kuliah Tidak Menunggak" AND Absen "SP" AND Nilai "Mengulang" THEN “ Non aktif"

- IF "Pembayaran Uang Kuliah Tidak Menunggak" AND Absen "Mengulang" THEN "Non aktif"

\section{Kesimpulan}

Berdasarkan penelitian diatas disimpulkan bahwa rule - rule yang dihasilkan menghasilkan kriteria-kriteria yang tepat dalam menganalisa mahasiswa yang berpotensi non aktif. Kriterianya adalah jadwal kuliah, nilai absensi, nilai gagal, pembayaran uang kuliah yang dapat mempengaruhi keputusan pada status mahasiswa aktif dan non aktif.

\section{Daftar Rujukan}

[1] Departemen Pendidikan Nasional, (2007) Buku I Naskah Akademik Akreditasi Institusi Perguruan Tinggi. Badan Akreditasi Nasional Perguruan Tinggi (BAN-PT).

[2] Artha K..J., Indrawan G \& Dantes D.R. (2016), Data Mining Rekomendasi Calon Mahasiswa Berprestasi di STMIK Denpasar Menggunakan Metode Technique For Others Preference By Similarity to Ideal Solution. Jurnal Sains dan 
Teknologi, 15( 2), 2303-3142. http://dx.doi.org/10.23887/jstundiksha.v5i2.8549.

[3] Elmande Y \& Widodo P. (2012), Pemilihan Criteria Splitting dalam Algoritma Iterative Dichotomiser 3 (ID3) untuk Penentuan Kualitas Beras Perum Bulog Drive Lampung. Jurnal Telematika MKOM, 06(1), 2085-7250.

[4] Novandya A, (2017), Penerapan Algoritma Klasifikasi Data Mining C4.5 Pada Dataset Cuaca Wilayah Bekasi. Konferensi Nasional Ilmu Sosial dan Teknologi. Vol 1, no 1.

[5] Lorena, S., Zarman, W., \& Hamidah, I. (2014). Analisis Dan Penerapan Algoritma C4.5 Dalam Data Mining Untuk Memprediksi Masa Studi Mahasiswa Berdasarkan Data Nilai Akademik. Prosiding Seminar Nasional Aplikasi Sains Dan Teknologi (SNAST), (November), 263-272.

[6] Harryanto, F. F., \& Hansun, S. (2017). Penerapan Algoritma C4.5 untuk Memprediksi Penerimaan Calon Pegawai Baru di PT WISE. Jurnal Teknik Informatika Dan Sistem Informasi, 3(2), 95-103.

[7] Melissa, I., \& Oetama, R. S. (2013). Analisis Data Pembayaran Kredit Nasabah Bank Menggunakan Metode Data Mining.
Jurnal ULTIMA InfoSys, 4(1), 18-27. https://doi.org/10.31937/si.v4i1.238.

[8] Novriansyah D., Erwansyah K., \& Ramadhan M. (2016), Penerapan Data Mining dengan Algoritma Naive Bayes Clasifier untuk Mengetahui Minat Beli Pelanggan terhadap Kartu Internet XL (Studi Kasus di CV. Sumber Utama Telekomunikasi). Jurnal SAINTIKOM, 15(2).

[9] Utama T.D., Sari W S, \& Afrizal D., (2014), Implementasi Iterative Dichotomiser 3 Pada Penyeleksian Program Mahasiswa Wirausaha UNS. Jurnal ITSMART, 3.

[10]Rhamadianoor \& Boy A.R., (2015), Sistem Pendukung Keputusan Penerima Beasiswa Dengan Metode Decision Tree. Jurnal Ilmiah Pendidikan, 12 (2).

[11]Lakshmi, B. N., Indumathi, T. S., \& Ravi, N. (2016). An Hybrid Approach for Prediction Based Health Monitoring in Pregnant Women. Procedia Technology, 24, 1635-1642. https://doi.org/10.1016/j.protcy.2016.05.171.

[12]Kusrini \& Lutfhi E.T, (2019). Algoritma dan Data Mining. Yogyakarta: Andi Publisher. 